DOI: $10.21802 / \operatorname{artm} .2020 .3 .15 .210$.

УДК $616-071+616-092+616.85$

\title{
ДІАГНОСТИКА ТАКСАН-ІНДУКОВАНОЇ ПЕРИФЕРИЧНОЇ НЕЙРОПАТІЇ У ОНКОЛОГІЧНИХ ХВОРИХ
}

\author{
І.С. Голотюк ${ }^{1}$, А.С. Крижанівська ${ }^{2}$, В.В. Голотюк ${ }^{3}$, А.В. Андріїв ${ }^{4}$, С.І. Голотюк ${ }^{5}$ \\ Івано-Франківський наиіональний медичний університет, кафедра онкологї̈, \\ м. Івано-Франківськ, Україна \\ ${ }^{1}$ ORCID ID: 0000-0002-3054-3140,e-mail:ivan.holotiuk@gmail.com, \\ ${ }^{2}$ ORCID ID: 0000-0003-4415-4696, ${ }^{3}$ ORCID ID: 0000-0003-4798-6893, \\ ${ }^{4}$ ORCID ID: 0000-0002-4905-5497, ${ }^{5}$ ORCID ID: 0000-0002-6712-2913
}

Резюме. На даний час немає стандартизованого підходу до клінічної оцінки хіміотерапевтичноіндукованої нейропатії. Однак існує консенсус у тому, що діагностика хіміотерапевтично-індукованої периферичної нейропатії повинна включати в себе як об'єктивні ознаки неврологічних розладів, так і оцінку симптомів з точки зору пацієнта. Причиною саме такого підходу є розбіжності у результатах клінічного обстеження та самооцінкою пацієнтами важкості свого стану. Зазвичай дані клінічного обстеження пацієнтів недооцінюють важкість побічних реакцій під час хіміотерапії. Діагностика хіміотерапевтично-індукованої периферичної нейропатії включає в себе опитувальники, оціночні шкали та об'єктивні методи дослідження нейрофізіологічних змін периферичної нервової системи, такі як електроміографія та кількісне сенсорне тестування. Оціночна шкала повинна володіти широким спектром показників, до яких входять клінічні симптоми, об'єктивні ознаки втрати чутливості та нейрофізіологічні параметри. Не менш актуальним є анкетування із самооцінкою свого стану пацієнтами в рамках клінічного дослідження. Включення оцінок, отриманих безпосередньо від пацієнтів, дозволяє провести більш комплексне та детальне вивчення хіміотерапевтично-індукованої периферичної нейропатії, удосконалює розуміння впливу симптомів нейропатії на пацієнтів та покращує узгодженість даних об’єктивного обстеження із результатами оцінки фукціональних змін.

Хіміотерапевтично-індуковану периферичну нейропатію необхідно диференціювати із нейропатіями іншого генезу, зокрема діабетичною та паранеопластичною нейропатіями. Запорукою своєчасної диференціальної діагностики є ретельне обстеження пацієнтів до початку хіміотерапії нейротоксичними препаратами 3 метою виявлення передіснуючої нейропатії.

Ключові слова: хіміотерапія, таксани, паклітаксел, периферична нейропатія, діагностика.

Вступ. Хіміотерапевтично-індукована периферична нейропатія $є$ одним із найчастіших неврологічних ускладнень, 3 яким доводиться мати справу пацієнтам, які отримують хіміотерапію. Ураження периферичної нервової системи при хіміотерапії може негативно впливати на щоденну діяльність і призводити до серйозного погіршення якості життя пацієнтів. Саме тому так важливо своєчасно діагностувати хіміотерапевтично-індуковану периферичну нейропатію та, якщо можливо, вберегти пацієнта від небажаних наслідків чи втрати функціональної активності. Розробка стандарту обстеження, а також впровадження нових методів діагностики хіміотерапевтично-індукованої периферичної нейропатії вдосконалить дизайн майбутніх наукових досліджень i, таким чином, прискорить впровадження майбутніх нейропротекторних засобів.

Диференціальна діагностика хіміотерапевтично-індукованої периферичної нейропатії. Прояви хіміотерапевтично-індукованої периферичної нейропатії можуть бути неспецифічними та співпадати із симптомами інших форм периферичної нейропатії. Належне обстеження пацієнтів на первинному етапі до початку проведення хіміотерапії потенційно нейротоксичними препаратами сприяє виявленню пацієнтів із передіснуючими сенсорними нейропатіями. Таким чином, встановлення взаємозв'язку між початком хіміотерапії та прогресуванням неврологічної симптоматики допоможе розпізнати пацієнтів із хіміотерапевтично-індукованою периферичною нейропатією.

У ряді випадків паранеопластичні нейропатії, при яких онконейронні антитіла уражають антигенні детермінанти периферичної нервової системи, зумовлюють неврологічну симптоматику, яка в деяких випадках нагадує хіміотерапевтично-індуковану периферичну нейропатію. Паранеопластичні нейропатії можуть проявляти себе як до встановлення діагнозу злоякісного новоутворення, так і навпаки, можуть виникати вже на фоні протипухлинної терапії. Як наслідок, диференціальна діагностика між хіміотерапевтично-індукованою та паранеопластичною нейропатіями може бути затруднена [1]. Пацієнти з паранеопластичними нейропатіями здебільшого демонструють виражену втрату пропріоцептивної чутливості в проксимальних ділянках та швидке прогресування втрати працездатності, що не $є$ притаманним для хіміотерапевтично-індукованої периферичної нейропатії. Підгостра сенсорна нейропатія $є$ найчастішим проявом паранеопластичної нейропатії, і типо- 
во представлена сенсорною атаксією та болем, хоча може проявлятися також вираженими симптомами ураження автономної нервової системи. Підгостра сенсорна нейропатія може бути пов'язана з аутоімунною агресією проти нейрональних антигенів (анти-Нu антитіла) у пацієнтів із дрібноклітинним раком легень, дещо рідше у хворих на рак грудної залози та хворобу Ходжкіна. У пацієнтів із дрібноклітинним раком легень та тимомою наявність антитіл до нейронних антигенних детермінант (анти-CV2 антитіл) може стати причиною сенсорно-моторної периферичної нейропатії в поєднанні із ураженням центральної нервової системи [2].

Злоякісні захворювання крові (гемобластози) також асоціюються зі паранеопластичними нейропатіями. До початку лікування множинної мієломи паранеопластичну нейропатію діагностували у $20 \%$ хворих та більш ніж у половини спостерігали ознаки дисфункції нервових волокон малого та великого діаметру. При цьому найчастіше розвивається помірна аксональна сенсорно-моторна нейропатія, яка у випадку застосування нейротоксичних хіміопрепаратів призводить до розвитку більш важкої периферичної нейропатії [3].

Рідкісний паранеопластичний POEMSсиндром (полінейропатія, органомегалія, ендокринопатія, моноклональна гаммапатія, зміни зі сторони шкіри) спостерігається у хворих 3 парапротеїнемічними формами гемобластозів. Провідним у клінічній картині захворювання $є$ синдром хронічної прогресуючої сенсорно-моторної полінейропатії, який зазвичай і $є$ причиною первинного звернення пацієнтів до невролога. Моноклональна гаммапатія, що $є$ передраковим попередником множинної мієломи, пов'язана 3 демієлінізуючою периферичною нейропатією, яка, в свою чергу, аналогічна хронічній запальній демієлінізуючій полінейропатії [4].

Наявність передіснуючої нейропатії, на кшталт POEMS-синдрому або хронічної запальної демієлінізуючої полінейропатії, $є$ протипоказом до хіміотерапії із застосування нейротоксичних середників.

Демієлінізуюча паранеопластична нейропатія зустрічається також у пацієнтів із лімфомою. Лімфома Вальденстрема, яка характеризується парапротеїнемією імуноглобулінів класу М, переважно асоціюється із аксональною нейропатією [5].

Оцінка хіміотерапевтично-індукованої периферичної нейропатії за допомогою оціночної шкали. Оцінка ступеня важкості нейропатії на даний час залишається достатньо умовною і багато в чому залежить від шкали, яка застосовується, та досвіду лікаря. Найбільш поширеною є шкала Національного інституту раку Сполучених Штатів Америки NCICTCAE (National Cancer Institute's Common Terminology Criteria for Adverse Events), а саме допоміжна шкала для оцінки сенсорної нейропатії (Neuropathy Sensory subscale). Шкала NCI-CTCAE володіє помірним рівнем надійності результатів та узгодженості висновків отриманих різними дослідниками. За даними експертів, надійність шкали NCI-CTCAE становить від $46 \%$ до $71 \%$. Ретельна підготовка дослідни- ків дозволяє отримати більш надійні результати, однак шкала Національного інституту раку лімітована так званим ефектом «стелі та підлоги» із обмеженим рівнем чутливості до змін, з огляду на малу кількість наявних ступенів важкості та параметрів $[6,7,8]$.

Total Neuropathy Score (TNS, розроблена університетом Джона Хопкінса) є комплексною шкалою із більшим діапазоном показників (0-40), які включають у себе клінічні симптоми, об'єктивні ознаки втрати чутливості та нейрофізіологічні параметри. Total Neuropathy Score (TNS) визнана багатьма багатоцентровими дослідженнями як надійний спосіб оцінки хіміотерапевтично-індукованої периферичної нейропатії. Total Neuropathy Score (TNS) достовірно корелює $з$ іншими показниками сенсорної дисфункції. Шкала університету Джона Хопкінса володіє широким діапазоном значень, що дозволяє провести більш точну градацію ступенів важкості хіміотерапевтично-індукованої периферичної нейропатії. Для прикладу, в одному з наукових досліджень 70 \% онкохворих, які отримували хіміотерапію нейротоксичними середниками, за шкалою NCI були розцінені як стабільні, однак по факту було наявне прогресуюче погіршення сенсорної нейропатії по шкалі Total Neuropathy Score (TNS). Клінічна версія Total Neuropathy Score (Clinical version, TNSc) включає тільки параметри клінічної оцінки без потреби застосування спеціалізованого обладнання. Скорочена версія TNS (Reduced version, TNSr) позбавлена тестування порогу вібраційної чутливості та оцінки моторних і вегетативних симптомів. Клінічна та скорочена версіï Total Neuropathy Score $\epsilon$ затвердженими для пацієнтів із хіміотерапевтично-індукованою периферичною нейропатією із високим рівнем узгодженості висновків, отриманих від різних дослідників $[9,10]$.

На даний час проводиться ряд наукових досліджень 3 метою визначення достовірно кращого методу оцінки хіміотерапевтично-індукованої периферичної нейропатії. До числа таких досліджень входить мультинаціональне дослідження CI-PeriNomS (Chemotherapy Induced-Peripheral Neuropathy Outcome Measures Study), яке зазначило високу достовірність та надійність ряду засобів для оцінки хіміотерапевтично-індукованої периферичної нейропатії. Важливо відмітити, що дослідження виявило хорошу достовірність і надійність оціночної шкали NCI-CTCAE, TNSc та опитувальників для самооцінки пацієнтом важкості нейропатії. Проте, за даними CI-PeriNomS, шкала Total Neuropathy Score (TNS) має відчутні переваги порівняно із шкалою NCI-CTCAE з точки зору чутливості до змін параметрів [11].

Отже, можна зробити висновок, що Total Neuropathy Score (TNS) є достовірним засобом оцінки хіміотерапевтично-індукованої периферичної нейропатії та може застосовуватись у майбутніх наукових дослідженнях, зокрема у вивченні та розробці нових нейропротекторних засобів.

Оцінка хіміотерапевтично-індукованої периферичної нейропатії за допомогою опитувальників. Анкетування із самооцінкою пацієнтами свого стану в рамках клінічного дослідження стає все більше важливим для забезпечення комплексного встано- 
влення важкості хіміотерапевтично-індукованої периферичної нейропатії. Виявляється, що пацієнти відзначають значно важчу нейропатію, ніж це роблять клініцисти. В одному із наукових досліджень, в якому брали участь 85 пацієнтів, які отримували хіміотерапію нейротоксичними препаратами, $19 \%$ повідомляли про наявність у себе симптомів нейропатії, при цьому 56 \% із них страждали від симптомів нейропатії помірного та важкого ступеня. Натомість, лікарі оцінювали тільки $12 \%$ пацієнтів від тієї ж когорти, як таку, що з наявністю клінічної симптоматики нейропатії, при цьому 90 \% пацієнтів були класифіковані як такі, що мають симптоми легкої нейропатії [12]. За результатами іншого дослідження, в якому взяло участь 696 пацієнтів, які отримували хіміопрепарат оксаліплатин, була 65 \% узгодженість між результатами анкетування та висновками клініцистів на основі критеріїв нейротоксичності, але варто зазначити, що пацієнти відзначали у себе початок нейропатії на 2 місяці раніше, ніж це робили клініцисти [13].

Таким чином, анкетування в рамках клінічного дослідження дає точнішу оцінку важкості нейропатії. 3 цією метою застосовується ряд опитувальників, у тому числі опитувальник Європейської організації із дослідження та лікування раку QLQCIPN20, опитувальник функціональної оцінки злоякісних новоутворень та онкогінекологічних захворювань стосовно нейротоксичності - FACT/GOG-Ntx (Functional Assessment of Cancer/Gynecologic Oncology Group-Neurotoxicity) та опитувальник для пацієнта щодо нейротоксичності PNQ (Patient Neurotoxicity Questionnaire). Крім того, майбутні версії оціночної шкали NCI будуть включати в себе відповідне анкетування [14].

Опитувальник FACT/GOG-Ntx, який містить 12 запитань стосовно нейропатії, $\epsilon$ затвердженим засобом оцінки нейропатії із високою внутрішньою узгодженістю закладених параметрів. Опитувальник FACT/GOG-Ntx тісно корелює 3 показниками щоденного функціонування, якістю життя пацієнта та об'єктивними даними стосовно нейропатії [15]. Для прикладу, за допомогою опитувальника FACT/GOGNtx в одному з досліджень встановлено, що у $81 \%$ пацієнтів, які отримували препарат бортезоміб була нейропатія, у той час як об'єктивне ретельне неврологічне обстеження ідентифікувало аналогічно 83 \% пацієнтів із даним ускладненням. Даний опитувальник забезпечує більшу чутливість параметрів із кожним збільшенням ступеня важкості за даними оціночної шкали NCI CTCAE, що відповідає 4-6 пунктам погіршення відповідно до опитувальника FACT/GOG-Ntx. Результати опитувальника FACT/GOG-Ntx корелюють 3 кількісними показниками пошкодження нерва, включно із даними визначення порогу вібраційної чутливості $[14,16]$.

Опитувальник FACT/GOG-Ntx також корелює із показниками повсякденного функціонування та якістю життя, що дозволяє оцінити вплив на функціональну активність [15]. Однак систематичний огляд досліджень, які включали в себе опитувальник FACT/GOG-Ntx, вказує на помірний рівень якості останнього (4,5 3 7) [17]. Деякі дослідники також повідомляли про рівень внутрішньої узгодженості параметрів опитувальника FACT/GOG-Ntx від помірного до високого (діапазон Кронбаха $\alpha, 0.82-0.94$ ) [14, $18]$.

QLQ-CIPN20 є аналогічним опитувальником 3 хорошою надійністю та більшою чутливістю, порівнюючи із оціночною шкалою NCI CTCAE. Недавнє дослідження підтвердило достовірність та точність опитувальника QLQ-CIPN20 в поєднанні із хорошим рівнем узгодженості внутрішніх параметрів (Кронбах $\boldsymbol{\alpha}, 0.88)$ та високою чутливістю до показників (Кохен $d, 0.82)[14,19]$.

Опитувальник PNQ (Patient Neurotoxicity Questionnaire) володіє більшим, порівнюючи із шкалою NCI CTCAE, набором параметрів щодо визначення важкості нейропатії, включає оцінку впливу симптомів нейропатії на функціональну активність. Опитувальник PNQ $є$ валідованим та чутливим засобом оцінки пацієнтів із хіміотерапевтичноіндукованою периферичною нейропатією [14, 20$]$.

3 огляду на зростаюче значення анкетування пацієнтів рекомендується застосовувати вищевказані опитувальники в дослідженнях, що стосуються хіміотерапевтично-індукованої периферичної нейропатії. Включення оцінок, отриманих безпосередньо від пацієнтів, дозволяє провести більш комплексне та детальне вивчення хіміотерапевтично-індукованої периферичної нейропатії, вдосконалює розуміння впливу симптомів нейропатії на пацієнтів та покращує узгодженість даних об'єктивного обстеження із результатами оцінки фукціональних змін.

Об'сктивна оцінка хіміотерапевтичноіндукованої периферичної нейропатії. Основним методом об'єктивної оцінки хіміотерапевтичноіндукованої периферичної нейропатії $\epsilon$ електроміографія, яка дозволяє виміряти амплітуду та швидкість провідності сумарних сенсорних та моторних потенціалів дії. Дослідження нервової провідності надає цінну інформацію про ступінь та протяжність аксональної дегенерації у пацієнтів із хіміотерапевтичноіндукованою периферичною нейропатією. Зниження амплітуди сумарного сенсорного потенціалу дії $\epsilon$ частою знахідкою, що, у свою чергу, підтверджує наявність у пацієнтів аксональної сенсорної нейропатії. Дослідження нервової провідності надає комплексну оцінку швидкості провідності, тимчасової диспеpсії, блоку провідності та оцінку більш проксимальних латентностей F-хвилі, що має вирішальне значення для диференціації хіміотерапевтичноіндукованої нейропатії із нейропатіями іншого генезу, зокрема запальними нейропатіями. Електроміографія є єдиним доступним у рутинній практиці методом, який дозволяє об'єктивно оцінити амплітуду сумарного сенсорного та моторного потенціалу дії. Однак варто зауважити, що параметри провідності нерва можуть залишатись незмінними тривалий час протягом хіміотерапії. До того ж, електроміографія вимагає спеціалізованого обладнання та підготовленого персоналу і може викликати дискомфорт для пацієнта $[11,21,22,23]$.

Додатковим визнаним методом об'єктивної оцінки є дослідження збудливості нерва. Даний метод дозволяє ідентифікувати початок нейропатії до появи 
клінічно значимих симптомів та до виникнення змін при електроміографії. Одним із методів дослідження збудливості нерва $€$ кількісне сенсорне тестування (Quantitative sensory testing - QST). Кількісне сенсорне тестування - це методика об'єктивної оцінки температурної та больової чутливості мієлінових волокон малого діаметру (А $\delta)$ та низькомієлінізованих Cволокон, а також вібраційної чутливості. Суть даного методу можна визначити як аналіз відчуттів пацієнта, що виникають у відповідь на зовнішні подразники заданої інтенсивності. Вплив на шкіру подразника зростаючої та спадаючої інтенсивності дозволяє визначити поріг больової чутливості та сенсорних симптомів. Механічна чутливість до тактильних подразників оцінюється за допомогою ниток фон Фрея. Вібраційна чутливість вимірюється за допомогою електронного віброметра чи відкаліброваних камертонів. Визначення порогу сприйняття вібраційної чутливості в стопах є надійним способом кількісного сенсорного тестування у пацієнтів із нейропатією. Застосування відкаліброваних камертонів та ниток фон Фрея $\epsilon$ затвердженим способом кількісного об'єктивного визначення втрати чутливості у пацієнтів із периферичною нейропатією. Чутливість до уколу оцінюється за допомогою голок різної маси. Температурна чутливість і патологічні реакції на тепло і холод оцінюються за допомогою температурного зонда. Розвиток холодової гіпералгезії (зменшений поріг больової чутливості у відповідь на холодовий подразник) може стати у нагоді при передбаченні розвитку важкої нейропатії у пацієнтів. Такі засоби тестування дають об'єктивну оцінку функції нерва та можуть бути вжитими швидко, з коротким терміном підготовки спеціалістів. Метод кількісного сенсорного тестування призначений для ранньої діагностики та оцінки динаміки стану при невропатіях нервових волокон малого діаметру, які неможливо оцінити за допомогою електроміографії. На даний час застосування даного методу є загальноприйнятим у ранній діагностиці діабетично- та хіміотерапевтичноіндукованої невропатії. Крім того, метод підходить для кількісної оцінки механічної та термічної аллодинії та гіпералгезії. Його застосування дає можливість більш точно охарактеризувати больові нейропатичні синдроми та патофізіологічні механізми їх виникнення, а також надати оцінку лікуванню [24, 25, $26]$.

Розробка стандартизованих протоколів кількісного сенсорного тестування може підвищити точність і значимість даної методики для пацієнтів із хіміотерапевтично-індукованою периферичною нейропатією. В цілому, традиційні методи дослідження нервової провідності залишаються стандартом для оцінки нейропатії і повинні застосовуватись у клінічних випробуваннях нейропротекторних засобів для надання об'єктивних доказів пошкодження або нейропротекції нерва.

Висновки. Пацієнти із хіміотерапевтичноіндукованою периферичною нейропатією потребують комплексного обстеження із включенням опитувальників, оціночних шкал та об'єктивних методів, таких як електроміографія та кількісне сенсорне тестуван- ня. Розробка стандарту обстеження даної категорії пацієнтів удосконалить дизайн майбутніх наукових досліджень та прискорить впровадження нейропротекторних засобів, розробку нових методів профілактики та корекції.

\section{References:}

1. Staff NP, Grisold A, Grisold W, Windebank AJ. Chemotherapy-induced peripheral neuropathy: A current review. Ann Neurol. 2017 Jun;81(6):772-781. doi: 10.1002/ana.24951. Epub 2017 Jun 5. PMID: 28486769; PMCID: PMC5656281.

2. Antoine JC, Camdessanché JP. Paraneoplastic neuropathies. Curr Opin Neurol. 2017 Oct;30(5):513520. doi: 10.1097/WCO.0000000000000475. PMID: 28682959.

3. Mahmoudpour SH, Bandapalli OR, da Silva Filho MI, Campo C, Hemminki K, Goldschmidt H, Merz M, Försti A. Chemotherapy-induced peripheral neuropathy: evidence from genome-wide association studies and replication within multiple myeloma patients. BMC Cancer. 2018 Aug 15;18(1):820. doi: 10.1186/s12885-018-4728-4. PMID: 30111286; PMCID: PMC6094450.

4. Callaghan BC, Price RS, Chen KS, Feldman EL. The Importance of Rare Subtypes in Diagnosis and Treatment of Peripheral Neuropathy: A Review. JAMA Neurol. 2015 Dec;72(12):1510-8. doi: 10.1001/jamaneurol.2015.2347. PMID: 26437251; PMCID: PMC5087804.

5. Jongen JL, Broijl A, Sonneveld P. Chemotherapyinduced peripheral neuropathies in hematological malignancies. J Neurooncol. 2015 Jan;121(2):229-37.

6. Majithia N, Temkin SM, Ruddy KJ, Beutler AS, Hershman DL, Loprinzi CL. National Cancer Institute-supported chemotherapy-induced peripheral neuropathy trials: outcomes and lessons. Support Care Cancer. 2016 Mar;24(3):1439-47. doi: 10.1007/s00520-015-3063-4. Epub 2015 Dec 19. PMID: 26686859; PMCID: PMC5078987.

7. Tan AC, McCrary JM, Park SB, Trinh T, Goldstein D. Chemotherapy-induced peripheral neuropathypatient-reported outcomes compared with NCICTCAE grade. Support Care Cancer. 2019 Dec; 27(12):4771-4777. doi: 10.1007/s00520-019-04781-6. Epub 2019 Apr 10. PMID: 30972648.

8. Golotiuk IS, Golotiuk SI, Kryzhanivs'ka AYE, Horoshko SS. Funktsional'ni urazhennya peryferychnykh nerviv u khvorykh na rak hrudnoyi zalozy zumovleni zastosuvannyam preparatu paklitaksel. Naukovo-praktychna konferentsiya «Personifikatsiya likuvannya hormonozalezhnykh pukhlyn, m. Yaremche. Onkolohiya. 2015; 17(3): 181.

9. Kaplow, Roberta PhD, APRN-CCNS, AOCNS, CCRN; Iyere, Karen MSN, APRN, AGNP-C, ACCNS-AG. Grading chemotherapy-induced peripheral neuropathy in adults. Nursing: February 2017 - Volume 47 - Issue 2 - p 67-68 doi: 10.1097/01.NURSE.0000511823.41645.a1.

10. Molassiotis A, Cheng HL, Lopez V, et al. Are we mis-estimating chemotherapy-induced peripheral 
neuropathy ? Analysis of assessment methodologies from a prospective, multinational, longitudinal cohort study of patients receiving neurotoxic chemotherapy. BMC Cancer. 2019;19(1):132. Published 2019 Feb 8. doi:10.1186/s12885-019-53024.

11. Griffith KA, Dorsey SG, Renn CL, Zhu S, Johantgen ME, Cornblath DR, Argyriou AA, Cavaletti G, Merkies IS, Alberti P, Postma TJ, Rossi E, Frigeni B, Bruna J, Velasco R, Kalofonos HP, Psimaras D, Ricard D, Pace A, Galie E, Briani C, Dalla Torre C, Faber CG, Lalisang RI, Boogerd W, Brandsma D, Koeppen S, Hense J, Storey DJ, Kerrigan S, Schenone A, Fabbri S, Valsecchi MG; CI-PeriNomS Group. Correspondence between neurophysiological and clinical measurements of chemotherapy-induced peripheral neuropathy: secondary analysis of data from the CI-PeriNomS study. J Peripher Nerv Syst. 2014 Jun;19(2):127-35.

12. Salgado TM, Liu J, Reed HL, et al. Patient factors associated with discrepancies between patientreported and clinician-documented peripheral neuropathy in women with breast cancer receiving paclitaxel: A pilot study. Breast. 2020;51:21-28. doi:10.1016/j.breast.2020.02.011.

13. Morton RF, Sloan JA, Grothey A, et al. A comparison of simple single-item measures and the common toxicity criteria in detecting the onset of oxaliplatininduced peripheral neuropathy in patients with colorectal cancer.JClinOncol.2005; 23(suppl16): 8087.

14. Curcio KR. Instruments for Assessing ChemotherapyInduced Peripheral Neuropathy: A Review of the Literature. Clin J Oncol Nurs. 2016 Apr; 20(2):144-51. doi: 10.1188/16.CJON.20-01AP. PMID: 26991707.

15. Driessen CML, de Kleine-Bolt KME, Vingerhoets AJJM, Mols F, Vreugdenhil G. Assessing the impact of chemotherapy-induced peripheral neurotoxicity on the quality of life of cancer patients: the introduction of a new measure. Support Care Cancer. 2012;20:877881.

16. Richardson PG, Briemberg H, Jagannath S, et al. Frequency, characteristics, and reversibility of peripheral neuropathy during treatment of advanced multiple myeloma with bortezomib. J Clin Oncol. 2006;24:3113-3120.

17. Griffith KA, Merkies ISJ, Hill EE, Cornblath DR. Measures of chemotherapy-induced peripheral neuropathy: a systematic review of psychometric properties. JPeripher Nerv Syst. 2010;15:314-325.

18. Park SB, Goldstein D, Krishnan AV, Lin CS, Friedlander ML, Cassidy J, Koltzenburg M, Kiernan MC. Chemotherapy-induced peripheral neurotoxicity: a critical analysis. CA Cancer J Clin. 2013 NovDec;63(6):419-37. doi: 10.3322/caac.21204. PMID: 24590861.

19. Lavoie Smith EM, Barton DL, Qin R, et al. Assessing patient-reported peripheral neuropathy: the reliability and validity of the European Organization for Research and Treatment of Cancer QLQ-CIPN20 Questionnaire [published online ahead of print March 30, 2013]. Qual Life Res.

20. Shimozuma K, Ohashi Y, Takeuchi A, et al. Taxaneinduced peripheral neuropathy and health-related quality of life in postoperative breast cancer patients undergoing adjuvant chemotherapy: N-SAS BC 02, a randomized clinical trial. Support Care Cancer. 2012;20:3356-3364.

21. Argyriou AA, Park SB, Islam B on behalf of the Toxic Neuropathy Consortium (TNC), et al Neurophysiological, nerve imaging and other techniques to assess chemotherapy-induced peripheral neurotoxicity in the clinical and research settings Journal of Neurology, Neurosurgery \& Psychiatry 2019;90:1361-1369.

22. Golotiuk IS, Kryzhanivs'ka AYE, Golotiuk VV, Andriyiv AV, Golotiuk SI. Mekhanizm rozvytku taksan-indukovanykh neyrofiziolohichnykh zmin $\mathrm{u}$ onkolohichnykh khvorykh. Naukovo-praktychnyy zhurnal «Art of medicine». 2019; 4 (12): 166-171.

23. Yoshida Y, Satoh A, Yamada T et al. The Relationship Between Evaluation Methods for Chemotherapy-Induced Peripheral Neuropathy. Sci Rep 9, 20361 (2019). https://doi.org/10.1038/s41598019-56969-9.

24. Lieber S, Blankenburg M, Apel K, Reindl T, Driever Pablo. (2016). Quantitative Sensory Testing Is Highly Sensitive in Detecting Chemotherapy-Induced Peripheral Neuropathy. Neuropediatrics. 47. 10.1055/s-0036-1583708.

25. Flatters SJL, Dougherty PM, Colvin LA. Clinical and preclinical perspectives on Chemotherapy-Induced Peripheral Neuropathy (CIPN): a narrative review. $\mathrm{Br}$ J Anaesth. 2017 Oct 1;119(4):737-749. doi: 10.1093/bja/aex229. PMID: 29121279.

26. Zhang X, Chen WW, Huang WJ. Chemotherapyinduced peripheral neuropathy. Biomed Rep. 2017 Mar;6(3):267-271. doi: 10.3892/br.2017.851. Epub 2017 Jan 27. PMID: 28451384; PMCID: PMC5403454.

\section{УДК 616 - 071+ 616-092 + 616.85 \\ ДИАГНОСТИКА ТАКСАН- ИНДУЦИРОВАННОЙ ПЕРИФЕРИЧЕСКОЙ НЕЙРОПАТИИ У ОНКОЛОГИЧЕСКИХ БОЛЬНЫХ}

И.С. Голотюк ${ }^{1}$, А.Е. Крыжанивская ${ }^{2}$, В.В. Голотюк ${ }^{3}$, А.В. Андриив ${ }^{4}$, С.И. Голотюк ${ }^{5}$

\section{Ивано-Франковский нацииональный медицинский университет, кафедра онкологии, \\ 2. Ивано-Франковск, Украина, \\ ${ }^{1}$ ORCID ID: 0000-0002-3054-3140, \\ e-mail:ivan.holotiuk@gmail.com, \\ ${ }^{2}$ ORCID ID: 0000-0003-4415-4696, \\ ${ }^{3}$ ORCID ID: 0000-0003-4798-6893, \\ ${ }^{4}$ ORCID ID: 0000-0002-4905-5497, \\ ${ }^{5}$ ORCID ID: 0000-0002-6712-2913}

Резюме. В настоящее время нет стандартизированного подхода к клинической оценке химиотерапевтически-индуцированной нейропатии. Однако существует консенсус в том, что диагностика химиотерапевтически-индуцированной периферической нейропатии должна включать в себя как объективные признаки неврологических расстройств, так и оценку симптомов с точки зрения пациента. Причиной имен- 
но такого подхода являются различия в результатах клинического обследования и самооценкой пациентами тяжести своего состояния. Обычно данные клинического обследования пациентов недооценивают тяжесть побочных реакций при химиотерапии. Диагностика химиотерапевтически-индуцированной периферической нейропатии включает в себя опросники, оценочные шкалы и объективные методы исследования нейрофизиологических изменений периферической нервной системы, такие как электромиография и количественное сенсорное тестирование. Оценочная шкала должна обладать широким спектром показателей, в которые входят клинические симптомы, объективные признаки потери чувствительности и нейрофизиологические параметры. Не менее актуальным является анкетирование с самооценкой своего состояния пациентами в рамках клинического исследования. Включение оценок, полученных непосредственно от пациентов, позволяет провести более комплексное и детальное изучение химиотерапевтически-индуцированной периферической нейропатии.

Химиотерапевтически-индуцированную периферическую нейропатию необходимо дифференцировать с нейропатиями другого генеза, в частности диабетической и паранеопластической нейропатиями. Залогом своевременной дифференциальной диагностики является тщательное обследование пациентов до начала химиотерапии нейротоксичными препаратами, с целью выявления предсуществующих нейропатии.

Ключевые слова: химиотерапия, таксаны, паклитаксел, периферическая нейропатия, диагностика.

\section{UDC $616-071+616-092+616.85$ \\ DIAGNOSIS OF TAXAN-INDUCED PERIPHERAL NEUROPATHY IN ONCOLOGICAL PATIENTS}

I.S. Golotiuk ${ }^{1}$, A.E. Kryzhanivska ${ }^{2}$, V.V. Golotiuk ${ }^{3}$, A.V. Andriiv ${ }^{4}$, S.I. Golotiuk ${ }^{5}$

Ivano-Frankivsk National Medical University, Department of Oncology, Ivano-Frankivsk, Ukraine, ${ }^{1}$ ORCID ID: 0000-0002-3054-3140, e-mail: ivan.holotiuk@gmail.com,

${ }^{2}$ ORCID ID: 0000-0003-4415-4696,

${ }^{3}$ ORCID ID: 0000-0003-4798-6893,

${ }^{4}$ ORCID ID: 0000-0002-4905-5497,

${ }^{5}$ ORCID ID: 0000-0002-6712-2913

Abstract. There is currently no standardized approach to the clinical evaluation of chemotherapyinduced neuropathy. However, there is consensus that the diagnosis of chemotherapy-induced peripheral neuropathy should include both objective signs of neurological disorders and assessment of symptoms from the patient's point of view. The reason for this approach is the discrepancy in the results of the clinical examination and the patients' self-assessment of the severity of their condition. Usually, clinical examination of patients underestimate the severity of adverse reactions during chemotherapy. Diagnosis of chemotherapy-induced peripheral neuropathy includes questionnaires, rating scales, and objective methods for studying of neurophysiological changes in the peripheral nervous system, such as electromyography and quantitative sensory testing. The rating scale should have a wide range of indicators, including clinical symptoms, objective signs of loss of sensitivity and neurophysiological parameters. A key characteristic of the rating scale is high sensitivity to changes in parameters. Not less relevant is the questionnaire with self-assessment of neuropathy by patients in a clinical trial. The inclusion of assessments obtained directly from patients allows for a more comprehensive and detailed study of chemotherapyinduced peripheral neuropathy, improves understanding of the effects of neuropathy on patients, and improves the consistency of objective examination data with the assessment of functional changes.

Chemotherapy-induced peripheral neuropathy should be differentiated from neuropathies of other genesis, in particular diabetic and paraneoplastic neuropathies. The key of differential diagnosis is a thorough examination of patients before chemotherapy with neurotoxic drugs, in order to identify pre-existing neuropathy. In some cases, paraneoplastic neuropathies, in which onconeuronal antibodies affect antigenic determinants of the peripheral nervous system, cause neurological symptoms, which in some cases resemble chemotherapy-induced peripheral neuropathy. Paraneoplastic neuropathies can be manifested both before the diagnosis of a malignant neoplasm, and vice versa, can occur against the background of anticancer therapy. As a result, the differential diagnosis between chemotherapy-induced and paraneoplastic neuropathies may be difficult. Paraneoplastic neuropathies can occur during chemotherapy, however, in contrast to chemotherapy-induced, they are characterized by a different clinical picture, such as loss of proprioceptive sensitivity in the proximal areas and others.

The main method of objective assessment of chemotherapy-induced peripheral neuropathy is electromyography, which allows to measure the amplitude and conduction velocity of the total sensory and motor action potentials. Quantitative sensory testing is also an objective method of assessing chemotherapy-induced peripheral neuropathy. The essence of this method can be defined as the analysis of the patient's sensations that arise in response to external pathogens of a certain intensity. The effect of the irritant on the skin of increasing and decreasing intensity allows to determine the threshold of pain, vibration, temperature, tactile sensitivity and sensory symptoms.

Keywords: chemotherapy, taxanes, paclitaxel, peripheral neuropathy, diagnosis. 